\title{
RITUAL SIKLUS KEHIDUPAN DI CIREBON ${ }^{1}$
}

\author{
Oleh: Busro \\ UIN Sunan Gunung Djati Bandung
}

\section{A. PENDAHULUAN}

Setiap manusia mengalami hal atau proses yang disebut siklus hidup, yaitu proses dimana seseorang lahir, menjadi dewasa, tua dan akhirnya meninggal. Tetapi terdapat beberapa perbedaan menyangkut cara dan proses manusia menyikapi siklus tersebut di berbagai daerah ataupun suku di setiap negara, hal ini dikarenakan adanya unsur kebudayaan di dalamnya.

Manusia adalah mahluk yang memiliki akal dan pikiran serta kebudayaan, kebudayan tersebut adalah hasil dari aplikasi akal dan pikiran manusia itu sendiri yang didasari oleh ide ataupun gagasan. Koentjaraningrat mengatakan bahwa kebudayaan berarti keseluruhan gagasan dan karya manusia yang harus dibiasakan dengan belajar serta keseluruhan dari hasil budi pekertinya. $^{2}$

Kata kebudayaan berasal dari bahasa Sansekerta buddayah, yaitu bentuk jamak dari kata buddhi yang berarti budi atau akal. Sehingga, kebudayaan dapat diartikan sebagai hal-hal yang berkaitan dengan akal. Oleh karenanya, budaya selalu dibedakan dengan kebudayaan. ${ }^{3}$

Indonesia merupakan negara kesatuan yang dibangun di atas kemajemukan. Sebagai bangsa yang majemuk, Indonesia terdiri dari berbagai suku bangsa, bahasa, agama, dan kebudayaan. Masyarakat bangsa Indonesia masih memegang teguh dan memelihara budayanya. Pemeliharaan kebudayaan ini berlanjut dan dilaksanakan sejak seseorang dilahirkan bahkan sampai ia mati.

Salah satu yang masih terperlihara adalah berbagai ritual yang dilaksanakan masyarakat dalam hubungannya dengan masa-masa terterntu dalam hidupnya atau yang dalam istilah Van Gennep disebut ritual siklus hidup.

Selanjutnya Van Gennep menyatakan bahwa dalam tahap-tahap pertumbuhannnya sebagai individu, sejak ia lahir, kemudian masa kanak-kanaknya, melalui proses menjadi dewasa dan menikah, menjadi orang tua, hingga saatnya ia meninggal, manusia mengalami perubahanperubahan biologi serta perubahan dalam lingkungan sosial budayanya yang dapat mempengaruhi jiwanya dan menimbulkan krisis mental. Untuk menghadapi tahap pertumbuhannya yang baru, maka dalam lingkaran hidupnya itu manusia memerlukan regenerasi semangat kehidupan sosial tadi. Van Gennep malahan menganggap rangkaian ritus dan upacara sepanjang tahap-tahap pertumbuhan atau daur hidup individu sebagai rangkaian ritus dan upacara yang paling penting dan mungkin paling tua dalam masyarakat dan kebudayaan manusia dalam banyak kebudayaan ritus peralihan sangat pnting misalnya dalam upacara hamil tua,

\footnotetext{
${ }^{1}$ Disampaikan dalam diskusi Mata Kuliah Indigenous Religion yang diampu Prof. Dr. Abdul Rozak, M.Ag., pada Prodi Magister Religious Studies, Selasa 17 Februari 2015

${ }^{2}$ Koentjaraningrat, Pengantar Ilmu Antropologi, Penerbit Rineka Cipta, Jakarta: 2009, hlm. 28

3 Ibid., hlm. 148
} 
upacara saat anak-anak tumbuh, upacara memotong rambut yang pertama, upacara keluar gigi yang pertama, upacara penentuhan si bayi dengan tanah yang pertama kali, dan sebagainya. ${ }^{4}$

Hampir di beberapa daerah di Indonesia mengenal upacara siklus kehidupan tersebut. Salah satu daerah yang masih melaksanakan upacara tersebut adalah Cirebon. Masyarakat Cirebon ketika seorang hamil empat bulan maka diadakan acara Ngupati, berlanjut ketika mencapai usia kehamilan tujuh bulan ada upacara Memitu atau nujuh Bulan. Ketika sang bayi sudah lahir ada upacara, Puputan, Akikah, dan Mudun Lemah. Ketika mencapai usia dewasa dan melakukan pernikahan ada upacara Ritual Manten, sampai ketika manusia meninggal pun masih ada upacara seperti Tahlilan.

Penelitian ini untuk menegaskan bahwa tradisi Islam khas Cirebon sampai saai ini masih hidup dan dilakukan oleh masyarakat Cirebon, khusunya di Desa Kedungsana. Kedungsana adalah suatu desa di Kab. Cirebon yang masih menjalankan tradisi seperti ritual siklus kehidupan diatas. Dalam penelitian ini, penulis hanya memfokuskan pada sesajen untuk ritual dalam kehamilan, Ritual Manten, Mudun Lemah ketika bayi mencapai umur tujuh atau delapan bulan dan Ritual sekitar kematian.

Ritual dalam penelitian ini adalah bentuk atau metode tertentu dalam melakukan upacara keagamaan atau upacara penting, atau tatacara dan bentuk acara. ${ }^{5}$ Dengan demikian ritual ialah seperangkat tindakan yang selalu melibatkan agama atau magi, yang dimantapkan melalui tradisi. Ritus tidak sama persis dengan sebuah pemujaan, karena ritus merupakan tindakan yang bersifat keseharian. Ritus tersebut meliputi: ritus kelahiran, ritus fertilitas, ritus inisiasi, ritus kesehatan, ritus purifikasi dan ritus transisi. ${ }^{6}$

Sedangkan siklus kehidupan yang dimaksud adalah seperti yang telah disebutkan oleh Van Gennep di atas yang secara garis besar dalam penelitian ini terdiri dari kelahiran, perkawinan dan kematian. Dalam penelitian ini akan dipaparkan proses dan tatacara upacara siklus kehidupan beserta maknanya bagi pelau ritual maupun maknanya yang dirasakan oleh masyarakat sekitar, karena tidak dapat dipungkiri seperti mayoritas ritual lainnya yang sarat dengan makna dan symbol.

\section{B. KONDISI OBJEKTIF LOKASI PENELITIAN}

Lokasi dalam penelitian ini adalah Desa Kedungsana. Kedungsana merupakan daerah pedesaan di Kecamatan Plumbon Kabupaten Cirebon. Jumlah penduduk Desa Kedungsana pada tahun 2011 adalah 4010 jiwadengan komposisi 2002 jiwa laki-laki dan 2008 jiwa perempuan dan semuanya memeluk agama Islam. ${ }^{7}$

Desa Kedungsana mempunyai luas wilayah sebesar 126,44 Ha dan berbatasan langsung dengan Desa Dana Mulya disebelah utara, Desa Karang Asem di selatan, Desa Pesanggrahan di

\footnotetext{
${ }^{4}$ Koentjaraningrat, Ritus Peralihan di Indonesia, PN Balai Pustaka, Jakarta, 1985, hlm. 32

5 Afif HM., ed., Harmonisasi Agama dan Budaya di Indonesia, Balai Penelitian dan Pengembangan, 2009, Jakarta, hlm. 3

$6 \quad$ Nur Syam, Islam Pesisir, Penerbit LKiS, Yogyakarta, 2005, hlm. 18

7 Monografi Desa Kedungsana yang ditandatangani oleh Kuwu Sudianto
} 
barat dan Desa Tegal sari disemailah timur. Dengan jarak dari pusat kecamatan sejauh 1,5 Km, dari pusat kabupaten sejauh $15 \mathrm{Km}$ dan dari kota provinsi sejauh $122 \mathrm{Km}^{8}$

Wilayahnya adalah persawahan dan industri. Letak persawahan dan industri berdekatan dan terletak di bagian luar lokasi perumahan. Industri dan persawahan ini berada di bagian utara dan timur desa.

Pertanian adalah mata pencaharian utama di Kedungsana. Lahan Pertanian pertanian hampir mengelilingi desa ini. Padi merupakan tanaman pokok ketika musim rendeng (hujan) dan ketika musim kemarau diganti menjadi palawija seperti kacang panjang, kacang hijau, kacang sisil (kedelai), timun dan lain-lain. Sistem pengairan menggunakan semi irigasi. Perpaduan antara irigasi dan tadah hujan. Jadi setiap petak sudah membuat bor air sendiri untuk pengairan ketika musim kemarau. Bor air ini merupakan swadaya petani yang dekat dengan lokasi bor.

Industri yang berkembang adalah industri meubel dan rotan yang dibangun oleh investor dari luar desa Kedungsana. Industri ini masuk ke semua desa di Cirebon tidak terkecuali desa Kedungsana. Dari industri ini tenaga kerja dari Kedungsana banyak terserap di lebih dari lima pabrik berskala besar. Sedangkan yang skala kecil puluhan jumlahnya tersebar di berbagai blok di desa Kedungsana.

Kedungsana dialiri sungai kali Soka (gbr.3) yang membagi dua wilayah ini, pertama Sabrang Wetan (timur) dan Sabrang Kulon (barat). Di wilayah timur terdiri satu blok yaitu blok Jamar Jati. Di wilayah barat terdapat blok Nyimas, blok sampurna dan Blok Desa. Kantor pemerintahan desa terletak di sebelah barat. Hanya ada satu masjid utama yaitu masjid Baiturrahman yang terletak di depan kantor desa (gbr.4). Selain masjid kegiatan keagamaan dilakukan di Tajug atau Mushala yang tersebar disetiap blok.

Tingkat pendidikan masyarakat Kedungsana rata-rata masih tingkat SMP. Hanya sedikit yang meneruskan ke tingkat SMA apalagi ke perguruan tinggi. Beberapa sarana pendidikan yang ada diantaranya TPA Miftahul Muta'alimin, SDN Kedungsana 1 dan SDN Kedungsana 2. Untuk SMP dan SMA terletak di tetangga desa Kedungsana.

Di wilayah timur terdapat dua kompleks kuburan dan di barat hanya ada satu kompleks kuburan. Di komplek kuburan Makam Jero (timur) terdapat kuburan yang dianggap keramat yang merupakan sesepuh dari Desa Kedungsana (gbr.5). Disini setiap tahun dilakukan acara Sedekah Makam yaitu upacara syukuran desa dan mendoakan para leluhur.

Selain Makam Jero ada pula lokasi lain yang dikeramatkan yaitu Petilasan Nyimas Gandasari di blok Nyimas. Lokasi ini sering dijadikan tempat sesajen ketika menyelenggarakan hajatan. Ada juga kepercayaan yang menganggap air di masjid utama desa bisa menyembuhkan penyakit. Namun setelah berkembangnya wialayah ini kepercayaan mengenai air keramat dan tempat keramat semakin pudar sedikit demi sedikit.

\section{SELAMETAN MANTEN}

Selametan manten adalah upacara pernikahan masyarakat Kedungsana. Dalam pernikahan banyak ritual yang harus dilakukan. Sebelum acara pernikahan terlebih dahulu harus

$8 \quad$ ibid 
disiapkan seperti uleman, tarub, sesajen dan lain-lain. Seminggu sebelum akad nikah sahibul hajat atau dalam masyarakat Kedungsana disebut duwe gawe mulai membagikan uleman atau undangan kepada masyarakat sekitar, saudara, teman, dan lain-lain.

Masyarakat Kedungsana walaupun yang punya hajatan hanya satu keluarga namun undangan yang dibagikan dua jenis. Yang pertama undangan yang dilakukan oleh kedua mempelai, jadi sasaran undangan ini adalah kenalan, teman dan lain-lain dari kedua mempelai. Dan hasil kondangan dari undangan ini akan kembali kepada kedua mempelai. Yang kedua adalah undangan yang dilakukan oleh keluarga mempelai, bukan kedua keluarga, tapi hanya keluarga dimana acara pernikahan dilangsungkan. Dan hasil kondangan pun kembali kepada keluarga. Sehingga orang yang datang ke pernikahan atau kondangan berbeda-beda tujuan. Umumnya jika yang kondangan adalah orang dewasa atau orang tua, kondangannya ke keluarga mempelai, dan ketika yang kondangan anak muda hampir bisa dipastikan kondangannya ke mempelai.

Dalam pembagian undangan, menggunakan undangan hasil cetakan. Namun ada tradisi pembagian undangan yang masih dilakukan, yaitu undangan menggunakan jasa orang yang disewa oleh yang duwe gawe. Sampai saat ini tradisi ini masih dilakukan, biasanya orang yang jadi wakil ini adalah perempuan yang sudah tua. dan hanya kepada masyarakat atau saudara yang dekat-dekat saja, disekitar desa Kedungsana dan desa-desa tetangganya. Para wakil ini menggunakan kebaya dan kain tapi (kain panjang) yang dipakai untuk bawahan juga untuk dililitkan dikepala. Ketika sampai di rumah yang akan diundang, wakil ini mengucapkan salam dan maksud tujuannya. Seperti ini: "punten, kula perwakilan saking keluargi Mbok Senami lan Bapa Kadmina, ngundang sampeyan teng mantenan putrane. Akade dinten septu dalu minggu. Dienteni kedugiane."

Sementara undangan dibagikan keluarga yang duwe gawe juga mulai mengundang pengobeng, yaitu orang-orang yang membantu acara hajatan seperi tukang masak. Selain tukang masang pengobeng lainnya tidak perlu diundangpun sudah berdatangan, karena di masyarakat tradisi gotong royong masih terjaga. Menurut masyarakat, saudara itu bukan hanya saudara rahim, tapi tetanggapun adalah saudara.

Sehari sebelum hajatan, tarub (tenda hajatan) mulai dipasang. Pada saat itu juga sesajen sudah mulai diracik dan ditempatkan di tempat-tempat yang sudah ditentukan. Sesajen ditempatkan di teblok (nampan) yang terdiri $\operatorname{atas}^{9}$;

1. Jajanan werna pitu, seperti: roti, bolu, rengginang, kupat dan kupat lepet, pisang ambon, pisang emas, pisang angling (masing-masing pisang sebanyak satu arit).

2. Udud serutu dan kinang, untuk merokok dan nginang.

3. Tumpeng iwak petek, lengkap dengan bekakak ayamnya.

4. Bubur merah dan bubur putih yang ditempatkan pada wadah dari daun pisang.

5. Cabai merah dan bawang merah ditusuk pada sebuah lidi. 
6. Wedang lima werna yang isinya: air kopi manis dan pahit, teh manis dan teh pahit, air putih, air kawah (campuran santan dan kopi), rujak pisang yang terbuat dari gula merahdan pisang yang diiris dan diberi air panas.

7. Air putih dalam kendi dan kendi itu ditutup telur asin.

8. Cempor (lampu tradisional yang terbuat dari kaleng yang diberi minyak tanah dan sumbu.

9. Ukup atau dupa yang diberi areng menyala dan diletakkan menyan.

10. Kembang tujuh rupa, seperti kembang kingkong, kembang melati, kembang mawar warna merah dan putih, kembang kantil, kembang kenanga, dan kembang sepatu.

Semuanya berjumlah tiga untuk ditempatkan di tiga tempat yaitu tarub, ngandang beras, dan pawon. Untuk membuat sesajen itu uang nduwe gawe biasanya sampai menghabiskan uang Rp. 250.000,- sampai Rp. 300.000,-. Semua barang tersebut bisa didapatkan di warung atau di pasar. Masyarakat tidak merasa keberatan harus mengeluarkan jumlah yang besar untuk menyediakan sajen tersebut. Mereka dengan senang hati menyediakannya, walaupun harus berhutang, sebagai simbol keyakinan, kepasrahan dan meminta berkah pada arwah leluhur. Jika tidak dilakukan mereka takut terjadi hal-hal yang tidak diinginkan seperti ada kesurupan, makanan buat hajatan tidak enak, hujan pada saat hajatan. Pernah ada kejadian kata mereka, ketika ada hajatan terjadi kesurupan, dan yang kesurupan meyebut-nyebut kinang, akhirnya diberi sirih, gambir, apu, kinang untuk dimakan pada yang kesurupan agar sembuh. ${ }^{10}$

Walaupun acara belum mulai sajen sudah mulai ditempatkan. Sajen untuk tarub ditempatkan diluar rumah diberi tanda dengan tongkat kayu yang ditancapkan sebagai tanda bahwa dirumah itu akan dilangsungkan selametan manten.

Sajen tarub mempunyai makna bahwa sebentar lagi acara pernikahan akan segera dimulai, untuk mengundang rezeki, ngundang welas asih (mengundang rasa belas kasih dan akhirnya banyak yang datang untuk mendoakan dan memberi sumbangan). ${ }^{11}$

Sajen ngandang beras, ditempatkan di tempat beras atau masyarakat biasa menyebutnya pedaringan. Sajen ini diracik dan hanya boleh didoakan oleh orang yang akan menunggu ngandang beras. Penunggunya biasanya nenek-nenek, tugasnya menunggu api yang ada pada cempor agar tidak padam, api harus nyala terus. Pedaringan harus ditutup rapat dengan kain lawon putih. Api menyala dan lawon putih mempunyai makna banyak rezeki dan keselamatan. ${ }^{12}$

Sajen pawon, diletakkan di dapur. Dapur biasanya terletak diluar rumah dan dibuat dari bata dan pada salah satu pojok dapur diletakkan sajen ini. Sajen pawon sebagai simbol keselamatan, kelancaran dalam membuat masakan, makanannya matang dan rasanya enak. ${ }^{13}$

Pada hari pelaksanaan akad perkawinan, para tamu undangan mulai datang dari berbagai penjuru. ijab qabul biasanya dilaksanakan pada pagi atau siang hari. Setelah ijab qabul kedua mempelai bersanding di pelaminan, para tamu datang memberi salam dan membawa uang dalam

Wawancara dengan Bapak Syafii, Jumat tanggal 15 November 2012 WIB

ibid

ibid

ibid 
amplop sebagai sumbangan. Sumbangan diberikan kepada kedua mempelai atau kepada orang tuan mempelai tergantung siapa yang mengundangnya.

Uang sumbangan juga dimaknai sebagai budi yang harus dibalas. Jadi ketika mempelai menerima uang sumbangan dari seseorang, maka ketika yang memberi itu mempunyai hajatan maka dia harus kondangan juga sebagai balas budi.

Setelah memberi salam dan memberi sumbangan para tamu menuju meja prasmanan untuk kemudia makan. Setelah makan para tamu pulang setelah sebelumnya memberi salam tanda pamit.

Setelah acara selesai, ketiga sesajen tadi dibawa pulang oleh orang yang bertugas ditempat masing-masing. Sajen tarub untuk orang yang bikin tarub, sajen ngandang beras dibawa oleh nenek penunggu pedaringan, dan sajen pawon dibawa oleh tukang masak.

\section{Makna simbolis Sesajen}

Seperti yang telah disebutkan diatas, sajen itu terdiri dari berbagai barang dan kesemuanya mempunyai makna simbolis yang berbeda.

Kembang atau bunga pada sajen memiliki suatu aroma yang harum dan wangi. Keharuman di sini adalah keharuman diri manusia, artinya manusia harus menjaga keharuman namanya agar tidak tercemar. Oleh hal-hal yang bersifat sepele. Bunga juga melambangkan kesucian dan sifat halus, kesucian merupakan makna bunga melati, manusia harus memiliki perasaan halus, sehingga ia peka terhadap sekelilingnya. ${ }^{14}$

Bunga lainnya adalah bunga kantil, kantil adalah bahasa Cirebon yang artinya ikut. Istilah ini diungkapkan dalam kekantilan kebahagiaan, kekantilan rezeki, kekantilan ketentraman dan lain-lain. Semua ini menggambarkan adanya harapan kedua mempelai mewarisi sifat yang baik, yang menjadikan hidup mereka selamat da memperoleh kebahagiaan. ${ }^{15}$

Cabai merah dan bawang merah yang ditusukkan ke lidi, maksudnya untuk pelengkap tumpeng sebagai lalaban. Warna merah melambangkan sifat berani, seseorang harus berani jika ingin maju, yaitu berani berusaha dan berani berjuang. Sifat berani yang positif akan menuntun seseorang kepada keberhasilan dan kemakmuran. ${ }^{16}$

Air sebagai sumber kehidupan. Dengan adanya air kehidupan menjadi nyaman sesuai sifat air yang adem. Semua makhluk hidup baik manusia, hewan maupun tumbuhan membutuhkan air, maka dalam hidup ini air harus selalu ada. Dalam sesajen di atas terdapat berbagai jenis air, semuanya mempunyai maksud kenyamanan keselamatan dan kesejahteraan. ${ }^{17}$

Bubur abang dan bubur putih mempunyai makna bahwa bubur abang adalah alam nyata atau jasmaniah, dan bubur putih menggambarkan alam ruhaniah. Jadi maksud dari bubur abang dan bubur putih adalah permohonan keselamatan lahir dan batin dalam menjalani kehidupan. ${ }^{18}$

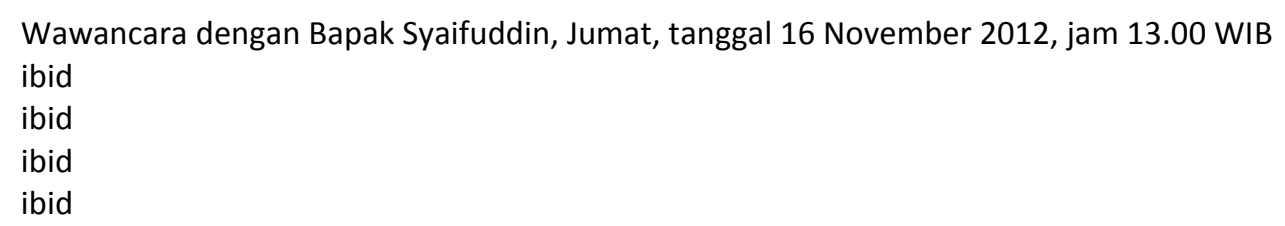


Api dalam cempor bertujuan menerangi kehidupan, sehingga tidak merasa kegelapan, dan hidupnya akan terarah dan lancar. Ukup atau menyan mempunyai makna wewangian dan menimbulkan rasa kasih sayang. ${ }^{19}$

\section{RITUAL SEKITAR KELAHIRAN}

Ada berbagai selamatan yang lazim dilakukan warga Desa Kedungsana dalam kelahiran. Diataranya adalah ketika umur kandungan 2 bulan dilaksanakan Ritual Mapag Widungan, setelah 3 bulan ada Ritual njaluk ning Pengeran, mencapai kandungan usia 4 bulan diadakan Ritual Ngupati, setelah 7 bulan ada Ritual Memitu, dan setelah mencapai 9 bulan ada upacara Ritual Nglolosi. Tidak berhenti sampai disini, setelah kelahiran sampai dikhitan masih banyak berbagai jenis Ritual yang akan dibahas satu persatu di bawah ini.

\section{Ritual Mapag Widungan}

Mapag Widungan artinya menyambut kandungan. Ritual ini dilaksanakan ketika usia kandungan mencapai dua bulan. Acaranya yaitu membaca Al-Quran, terutama surat Lukman dan Tabarok, maksudnya agar kelak calon anak tersebut meneladani Lukman dan mendapat berkah dari Allah SWT. Seperti ritual yang lainnya dalam Ritual ini pun dilanjutkan dengan syukuran makan-makan. Namun seperti kata Ustad Syaifuddin, dalam syukuran ini tidak dipaksakan, artinya disesuaikan dengan kemampuan masing-masing.

\section{Ritual Njaluk ning Pengeran}

Ritual ini dilaksanakan ketika kandungan berusia tiga bulan. Maksudnya yaitu orang tua meminta atau njaluk kepada Allah SWT mengenai sifat atau jenis kelamin calon anaknya. Orang tua berdoa kepada Allah dibantu oleh jamaah yang hadir dalam acara tersebut agar anaknya kelak memenuhi harapan orang tua. Masyarakat Kedungsana meyakini ketika usia kandungan dibawah umur empat bulan, calon bayi masih belum dituliskan ketetapannya, sehingga pada waktu-waktu ini dianjurkan banyak-banyak berdoa.

\section{Ritual Ngupati}

Ritual ini dilakukan ketika usia kandungan mencapai empat bulan. Ngupati artinya membuat sifat, karena pada usia kandungan 4 bulan Allah menetapkan sifat manusia. Di harapkan Allah menetapkan sifat kepada anak tersebut dengan sifat yang baik-baik.

Menurut Syafii dalam ngupati acaranya yaitu ngaji bersama membaca surat Waqi'ah, Yaasin, Maryam, Yusuf. Menurut beliau Surat Yaasin itu mempunyai berkah untuk keselamatan. Surat Waqi'ah adalah harapan orang tua, agar kelak ketika anak lahir ke dunia mendapat banyak rizki. Surat Yusuf dan Maryam, agar nanti kalau anaknya laki-laki mempunyai rupa dan akhlak seperti nabi Yusuf dan jika perempuan dapat meneladani Siti Maryam ibu Nabi Isa AS. Intinya sifat-sifat yang ada dalam isi Al-Quran melekat dalam anak tersebut.

Dalam Ngupati, biasanya membuat ketupat untuk acara makan setelah pengajian tersebut. Kupat ini merupakan simbol leluhur zaman dulu untuk gawe sipat.

19

ibid 


\section{Ritual Memitu}

Tradisi memitu yang dilakukan oleh masyarakat Kedungsana merupakan bagian dari Ritual kehamilan mencapai umur tujuh bulan. Kebiasaan memitu ini sama seperti masyarakat Jawa pada umumnya, dalam rangka melaksanakan adat atau tradisi yang secara turun temurun telah dilaksanakan nenek moyang mereka. Meskipun dalam pelaksanaanya berbeda-beda antar satu daerah dengan daerah lain di Cirebon. Persiapan dan perlengkapan untuk melaksanakan upacara memitu ini sendiri adalah pertama-tama disiapkannya bahan-bahan untuk keperluan upacara yakni :

- Jarit atau tapi (kain panjang) 7 lembar dan masing-masing lembarnya memiliki warna yang berbeda.

- Miniatur rumah-rumahan yang sudah dihias

- Pendil atau belanga (semacam tembikar yang pada jaman dulu dipakai untuk mengambil air) yang berisi air, berbagai jenis tanaman dan beberapa uang logam

- Kembang tujuh rupa

- Sesaji yang berisi antara lain : Nasi wuduk, Juwadah pasar, Rujak parud, rujak asem, rujak pisang, rujak selasih, Aneka buah dan umbi, dan tebu wulung.

- Kelapa muda yang telah digambar salah satu tokoh wayang (biasanya tokoh Arjuna).

Tradisi memitu biasanya dilakukan pada sore atau malam hari. Acara ini dimulai dengan pembacaan kitab Barzanji di rumah yang duwe gawe. Selain barzanji juga dibacakan Al-Qur'an Surat Yasin, Luqman, Maryam, Yusuf, An-Nur, dan Muhammad.

Ditengah-tengah orang yang sedang mengaji dan barzanjian diletakkan wadah yang berisi air. Air ini kemudian akan dicampurkan kedalam wadah air yang disediakan untuk mandi suami-istri di rumah-rumahan yang sudah disediakan diluar rumah.

Setelah yang mengaji dan barzanjian selesai, makanan dibagikan, dan air yang tadi dibawa keluar kemudian dicampurkan ke wadah yang ada di rumah-rumahan.

Pasangan mualai dimandikan, dimulai dari orang tua, saudara-saudara, sesepuh desa, dan dilanjutkan dengan jamaah pengajian tadi. Pada proses pemandian sang istri ini ketika dimandikan sang istri hanya memakai kain tapi dan bergantian diganti sampai tujuh kali. Dan pada saat pergantian kain yang ke tujuh itu, kemudian kelapa muda yang telah digambari tokoh wayang tadi dijatuhkan melalui dalam kain yang dipakai oleh si ibu hamil dan suami si ibu hamil yang sedari tadi ikut dimandikan diharuskan untuk menangkap kelapa muda itu sebelum jatuh ke tanah.

Selesai memandikan anak-anak disekitar mulai mengerubuti rumah-rumahan yang sudah dihias. Tanpa disuruh anak-anak mulai rebutan barang-barang hiasan rumah-rumahan. Dari mulai balon, bunga, hiasan dari kertas dan uang menjadi sasaran anak-anak. Dengan dibarengi curak, yaitu saweran uang receh.

Upacara ditutup dengan memecahkan pendil berisi air, kembang tujuh rupa dan uang logam. Sang suami setelah selesai dimandikan mengambil pendil kemudia berlari menuju perempatan jalan dan memecahkannya. Anak-anak kembali mengerubuti pecahan pendil mencari uang logam disana. 


\section{Makna Simbolis Memitu}

Selametan memitu yang dilakukan masyarakat Kedungsana merupakan bagian dari tradisi lokal meskipun diisi nilai-nilai keagamaan seperti pembacaan ayat Al-Qur'an dan pembacaan kitab Barzanji. Tradisi pembacaan Al-Quran dan Barzanji sangat penting dilakukan pada tradisi memitu, karena menurut masyarakat Kedungsana ketika janin dalam kandungan memasuki umur tujuh bulan, janin sudah sempurna, sudah memiliki struktur tubuh yang lengkap, bersih dan bebas dari dosa. ${ }^{20}$ Kondisi seperti ini menjadi kondisi sempurna untuk menjadi acuan bagi muslim yang baik dalam usaha spiritualnya.

Pembacaan tujuh surat Al-Quran bermakna agar anak ketika lahir menjadi baik dan saleh. Bila anaknya perempuan, diharapkan memiliki sifat-sifat seperti Siti Maryam ibunda Nabi Isa, sedangkan bila anaknya kelak laki-laki diharapkan seperti Nabi Yusuf yang ganteng, begitu seterusnya. Dalam pembacaan Barzanji diharapkan sang anak bisa meneladani sifat-sifat dan teladan Nabi Muhammad SAW.

Makna dibalik proses pemandian diniatkan sebagai pensucian. Diharapkan anak yang lahir kelak akan selalu bersuci dan rajin melaksanakan sholat. Makna filosofis dari dijatuhkannya kelapa muda pada saat dimandikan melambangkan kemudahan si ibu hamil saat melahirkan nanti, sedangkan gambar wayang yang terukir di kelapa sendiri sebagai symbol pengharapan bahwa sang jabang yang kelak akan dilahirkan memiliki paras dan kegagahan seperti yang dimiliki oleh si tokoh wayang yang di gambar tersebut.

\section{Ritual Nglolosi}

Ritual ini ketika kandungan mencapai usia sembilan bulan. Lolos artinya lancar. Jadi Ritual ini mengharapkan kelancaran ketika kelahiran. Lolos juga menjadi nama makanan bubur yang khusus dibuat untuk ritual ini. Bubur lolos adalah sejenis juada yang lunyu atau licin. Ini merupakan perlambang dan harapan kelahiran seperti bubur lolos ini yaitu licin atau lancar. Bubur ini disajikan saat makan-makan setelah pengajian dan juga dibagikan kepada tetangga.

\section{Ritual Mapag Bocah}

Ritual mapag bocah artinya menyambut sang anak ketika baru dilahirkan. Acaranya berdoa bersama sambil membaca Al-Quran dan dilanjutkan dengan bacakan yaitu makan secara bersama dalam tampah yang berisi nasi lengkap dengan lauknya, dan dilanjutkan dengan curak.

\section{Ritual Puputan}

Ritual ini dilakukan setelah puser bayi putus, umunya dilakukan antara umur 3-7 hari. Ketika Puputan juga sambil memberi nama untuk anak tersebut. Dan jika mampu sekalian melaksanakan Akikah, yaitu menyembelih kambing gibas, dua untuk laki-laki dan satu untuk perempuan. Acaranya sama seperti Ritual sebelumnya, yaitu dilakukan pembacaan al-Quran dan doa bersama atau pembacaan Barzanji.

Yang menarik, dalam acara Puputan juga dilakukan prosesi penguburan ari-ari. Menurut Bibi Asiri yang berprofesi sebagai paraji, ari-ari tersebut dimasukkan kedalam kendi dan ditutup dengan batok, ari-ari tersebut dicapur dengan garam agar tidak bau. Batok yang dipakai pun ada syarat khusus, yaitu batok bonglu (batok yang hanya mempunyai satu lubang). Dalam lubang 
tersebut dimasukkan batang lidi atau dalam bahasa Cirebon disebut sada. Dan setelah dikubur ditanami atau ditancapkan tanaman beringin dan pandan. ${ }^{21}$ Ketika mengubur ari-ari dilantunkan rapalan seperti dibawah ini: ${ }^{22}$

Bismillahirahmanirahim

Niat isun apan maca padang ati

Beli Duwe padang ati duwee damar sejati

Byar padang tirawangan anake atie isun

Nama bocah nya

Ya Fatah... Ya Fatah... Ya Fatah.

Makna dari Batok Bonglu menurut Syaifuddin yaitu bahwa pegangan didunia itu adalah tok kang siji atau hanya yang satu yaitu Allah YME. Adapun sada adalah simbol dari Syahadat. Dan pohon beringin artinya mengayomi dan tidak membahayakan, adapaun pandan adalah sifat amis budi.

\section{Ritual Nyukur}

Setelah 40 hari, diadakan Ritual nyukur, acaranya yaitu mencukur rambut bayi. Penyukuran ini dilakukan oleh jamaah pengajian dan dimulai oleh orangtuanya. Rambut hasil cukuran ini akan ditimbang dan diuangkan beratnya berdasarkan harga emas pada saat itu. Dan uang tersebut akan di sodaqohkan melalui curak.

Orang tua bayi membuat bubur lemu yang manis dan wangi. Maknanya agar kelak si anak mempunyai sifat baik, omonganya manis tingkah, laku manis. Dalam acara ini juga biasanya bisa sambil akikah.

\section{Ritual Mudun Lemah}

Mudun lemah adalah ritual turun tanah ketika bayi berumur 7 bulan. Maksudnya yaitu mengenalkan dan mempersiapkan sejak dini liku-liku kehidupan.

Acaranya yaitu bayi dinaikkan ke tangga dan turun ke tanah, diiringi doa. Tangganya terbuat dari tebu, maknanya karena tebu mempunyai banyak manfaat, diharapkan anak ini kelak bermanfaat disekitarnya. Dan tebu itu rasanya manis, diharapkan anak nantinya mempunyai tingkah laku yang baik. Di kiri kanan tangga tebu terdapat bendera merah putih dan panggang ayam. Merah putih merupakan wujud nasionalisme leluhur zaman dulu.

Bayi dinaik turunkan ke tangga sebanyak tiga kali dimulai dari atas, sambil yang menaikkan dan jamaah membaca sholawat. Setelah 3 kali terus bayi diajari jalan diatas macammacam barang seperti pasir, makanan, beras, emas sampai pada kotoran ayam. Ini maknanya kelak itu dalam kehidupan itu mengalami baik dan buruk, mengalami senang susah, jadi ketika nanti di masyarakat sudah siap menghadapi hidup tidak kaget lagi karena sudah dikenalkan sejak kecil. Sambil melaksanakan ritual naik tangga dan menginjak berbagai barang, di punggung sang bayi di beri gendongan batok yang berisi beras dan uang. Maksudnya agar setelah dewasa nanti dan berkeluarga jangan sampai kekurangan beras dan uang.

\section{Ritual Nyapih}

21

22

Wawancara dengan Bapak Tani, Kamis, tanggal 15 November 2012, jam 14.00 WIB

Wawancara dengan Bi Asiri, Kamis, tanggal 15 November 2012, jam 20.00 WIB 
Nyapih berasal dari kata sapih (bahasa Jawa) yang artinya pisah atau memisahkan. Dengan demikian Nyapih mempunyai arti upacara yang bertujuan untuk memisahkan hubungan menyusu antara anak dan ibunya. ${ }^{23}$ Waktu yang paling baik untuk menyapih bayi, jika bayi lakilaki ketika berumur 15-16 bulan, jika perempuan 18-19 bulan. Jika melebihi umur tersebut baru disapih, menurut kepercayaan saat dewasa, anak tersebut akan menjadi orang yang bodoh.

Pada saat nyapih, bagian puting payudara ibu diolesi dengan sesuatu yang pahit. Di Desa Kedungsana biasa menggunakan biji Emes (luffa cylindria) yang sudah tua yang ditumbuk yang kemudian dioleskan ke bagian puting payudara saat bayi meminta menyusu. Saat disapih inilah bayi akan sangat nakal, sering menangis dan bahkan mencakar ibunya. Untuk menenangkannya ini ada ritual unik yang masih beredar di Kedungsana. Rittual tersebut yaitu bayi digendong dan kepalanya benturkan ke salang (sejenis tambang) sambil dibacakan rapal: "ya salang, isun arep Nyapih.... (nama bayi), jangji salang nangis, ya nagisa kaya salang (ke bayi), jangji salang meneng bae, ya sing idep kaya salang. "24 Artinya ya salang, saya akan menyapih ... (disebutkan nama bayinya). Jika salang menangis, ya nangislah seperti salang, jika salang diam, ya diamlah seperti salang (bicara ke bayi).

Bentuk kalimat dan benda yang dipakai untuk objeknya bermacam-macam namun pada intinya merupakan pengharapan agar anak yang akan disapih ini menjadi idep (tidak rewel) seperti benda tersebut ketika disapih.

Menurut Mustikawati ${ }^{25}$, pelaksanaan segala ritual itu masuk dalam kategori sunnah, artinya kalau tidak dilakukan pun tidak mendapat hukum apa-apa, namun jika dilaksanakan mendapatkan pahala, karena dalam setiap prosesi ritual juga membaca Al-Qur'an yang dalam agama Islam membaca Al-Qur'an itu termasuk ibadah.

\section{E. RITUAL SEKITAR KEMATIAN}

Ketika ada yang meninggal manusia yang masih hidup mempunyai kewajiban yaitu:

\section{Memandikan}

Yang memandikan harus keluarga dan berjenis kelamin sama. Mandinya pertama menggunakan air biasa, setelah bersih dilanjutkan lagi menggunakan air kembang dan sabun. Dalam prosesi memandikan ini sambil dibacakan Sholawat Nuril Anwar :

Allahumma shalli 'alaa nuuril anwaari wasirril asraari, watiryaaqil aghyaari wamiftaahi baabil yasaari, sayyidinaa wamaulaana Muhammadinil muhtaari wa aalihil ath haari wa ash haabihil ahyaari 'adada ni'amillaahi wa ifdhaalih.

\footnotetext{
${ }^{23}$ Harmanto Bratasiswara, Bauwarna: Adat Tata Cara Jawa, Yayasan Suryasumirat, Jakarta, 2000, hlm 499

${ }^{24}$ Tradisi semacam ini juga berlaku di Jawa Tengah, bedanya jika di Jawa Tengah bayi dibenturkan di pohon pisang dan sebelumnya mengelilingi rumah tiga kali. Dan rapal yang dibaca proses menyapih di Jawa adalah " sang wewe putih, kowe dak opahi tape sapangaron, nanging janji bisa nyapih si jabang bayi, aja nganti nangis."

(Gunasasmita, Kitab Primbon Jawa Serbaguna, Narasi, Yogyakarta, 2009, hlm. 90)

${ }^{25}$ Mustikawati, Hasil Wawancara: Blok Sampurna, 10 Januari 2014
} 


\section{Mengkafani}

Menggunakan kain putih 7 meter sampai 12 meter sebanyak 3 lapis, belum menghitung baju kurung. Dan juga menggunakan 3 ikat benting, yang terdiri dari 1 untuk kepala, 1 untuk kaki dan 2 ditengah. Lawon ditaburi kembang dan minyak wangi. Kemudian disumpel kapas dan bore. Yang boleh melakukan ini adalah muhrimnya, itu juga yang satu jenis kelamin. Lebe bertugas hanya memberi contoh saja.

\section{Menyolatkan}

Setelah dikafani mayit kemudian disholatkan, jika mayitnya perempuan maka kepalanya ada di sebelah utara dan sebelah selatan untuk mayit laki-laki, namun menurut Syaifuddin, ini tidak menjadi persoalan ketika bingung kepalanya ada dimana dan tidak usah dibuka kembali kafannya atau kerandanya. Dan tidak jadi masalah apakah ketika mensholatkan penutup keranda dibuka atau ditutup. Setelah disholatkan kemudian pihak keluarga mengucapkan terima kasih kepada jamaah, dan mengumumkan hutang-hutang yang ditanggung mayit sekarang ditanggung keluarganya, dan dimintakan maaf apabila dulu mayit semasa hidup mempunyai kesalahan dan memohon keikhlasannya agar amal perbuatannya bisa diterima Allah SWT.

\section{Dikuburkan}

Setelah disholatkan mayit dibawa ke kuburan sambil membaca la ilaha illa Allah selama perjalanan. Sesampainya di kuburan kemudian dibacakan Adzan dan Iqamat, kemudian mayit dimasukkan liang lahat. Kepalanya di utara, menghadap kiblat dan iket kepala dibuka kemudian pipinya ditempelkan ke tanah. Diletakkan juga gelu, yaitu ganjalan yang terbuat dari tanah liat bekas galian kubur. Ada 3 gelu, yang diletakkan di kepala, di tengah dan di beyekan. Ketika membuat gelu sambil membaca surat Inna Anjalna.

\section{F. PENUTUP}

Mantenan merupakan salah satu perjalanan dari tahap kehidupan yang penting, karena merupakan awal peralihan dari satu tahap ke tahap yang lainnya, dan diharapkan berlangsung dengan lancar dan selamet. Jadi agar semuanya lancar dan selamet atau untuk merayakan syukuran keberhasilan melalui peralihan tahap maka diadakanlah selametan, atau hajatan, atau syukuran yang didalamnya disertai sesajen.

Sesajen adalah menghidangkan makanan, minuman, buah-buahan atau bunga kepada makhluk halus atau leluhur. Maksudnya untuk tolak bala agar apa yang diinginkan terkabul dan sukses, mengundang rezeki, keselamatan, kesehatan, kebahagiaan dan lain-lain.

Semua bahan-bahan yang ada di dalam sesajen semuanya mempunyai makna dan maksud tertentu, seperti pedaringan yang ditutup dengan kail putih bermakna mengundang rezeki, sesajen yang diluar rumah dan ditancapkan sebatang bambu bermakna informasi kepada masyarakat bahwa akan ada hajatan dirumah tersebut, dan lain-lain.

Ritual atau Ritual sekitar kelahiran merupakan tradisi yang dilakukan oleh sebagian besar masyarakat Islam di Cirebon, maka keberadaan tradisi ini memungkinkan diisi dengan nilai-nilai Islam, seperti pembacaan Al-Quran dan Kitab Barzanji. 
Tradisi ini tetap eksis di Cirebon, meskipun gempuran modernitas terus menggerus Cirebon. Tradisi sekitar kelahiran dan kematian di Cirebon tetap letari tidak terpengaruh dengan budaya-budaya modern tersebut. Hal ini terbukti dengan tingkat solidaritas dan memegang teguh tradisi lokal sangat kuat. Hal ini sejalan dengan sebutan Cirebon sebagai Kota Wali. 


\section{DAFTAR PUSTAKA}

Afif HM., ed., Harmonisasi Agama dan Budaya di Indonesia, Balai Penelitian dan Pengembangan, 2009, Jakarta

Clifford Geertz, Abangan, Santri, Priyayi dalam Masyarakat Jawa, Terjemahan Aswab Mahasin, Pustaka Jaya, Jakarta, 1983

Dadang Kahmad, Meetode Penelitian Agama Perspektif Ilmu Perbandingan Agama, Pustaka Setia, Bandung, 2000

Daliman, Upacara Garebek di Yogyakarta: Arti dan Sejarahnya, Penerbit Ombak, Yogyakarta, 2012

Daniel L. Pals, Dekonstruksi Kebenaran: Kritik Tujuh Teori Agama, penerjemah: Inyiak Ridwan Muzir dkk, Yogyakarta: IRCiSoD, 2001

Data Profil Desa Kedungsana Kecamatan Plumbon Kabupaten Cirebon, Pemkab Cirebon Badan Pemberdayaan Masyarakat dan Pemerintahan Desa, 2013

Eko A. Meinarno, et.al, Manusia Dalam Kebudayaan Dan Masyarakat Pandangan Antropologi dan Sosiologi, Salemba Humanika, Jakarta, 2011

Fischer, Pengantar Antropologi Kebudayaan Indonesia, Pustaka Sarjana, Surabaya, 1953

Gunasasmita, Kitab Primbon Jawa Serbaguna, Narasi, Yogyakarta, 2009

Harmanto Bratasiswara, Bauwarna: Adat Tata Cara Jawa, Yayasan Suryasumirat, Jakarta, 2000

Hilman Hadikusumah, Antropologi Agama Bagian I, Citra Aditya Bakti, Bandung, 1993

Koentjaraningrat, Pengantar IImu Antropologi, Penerbit Rineka Cipta, Jakarta: 2009

Koentjaraningrat, Ritus Peralihan di Indonesia, PN Balai Pustaka, Jakarta, 1985

Koentjaraningrat, Sejarah Teori Antropologi II, UI Press, Jakarta, 1990.

Nur Syam, Islam Pesisir, Penerbit LKiS, Yogyakarta, 2005

Nur Syam, Makalah-Makalah Antropologi, Penerbit LKIS, Yogyakarta, 2007

Romdon, Metodologi Ilmu Perbandingan Agama, Raja Grafindo Persada, Jakarta, 1996

Sulendraningrat, Sejarah Cirebon, Penerbit Nasional Balai Pustaka, Jakarta, 1974

Venny Indria Ekowati, Tata Cara Dan Upacara Seputar Daur Hidup Masyarakat Jawa Dalam Serat Tatacara, FBS Universitas Negeri Yogyakarta, Yogyakarta 